\title{
A RELAXÁCIÓS ÉS KÖZÉRZETJAVÍTÓ SZOLGÁLTATÁSOK AZ ÉSZAK -ALFÖLDI RÉGIÓ SZÁLLODÁINAK KÍNÁLATÁBAN
}

Biró Melinda - Pucsok József Márton - Hidvégi Péter - Lenténé Puskás Andrea

\section{Összefoglalás}

Az emberek az üdüléseik alatt szeretnének pihenni, kikapcsolódni, ellazulni, feltöltödni, igy a szolgáltatásokban is ezt keresik. Az élmény, a kényeztetés, az egészségtudatosság egyre inkább megjelenik az emberek üdülöhely megválasztását befolyásoló tényezőinél. Mivel az egészségre való törekvés, a relaxáció, a közérzetjavitás az üdülések során mint igény jelenik meg, ennek hatása a turisztikai desztinációk megválasztásakor is érvényesül, valamint a szolgáltatások preferencia rendszerében is visszatükrözödik. Mivel az Eszak-Alföldön az idegenforgalom szerepe fontos tényezö, a kutatásunk során ezen szolgáltatásokat vizsgáltuk, a régió 3-5 csillagos szállodában. 50 szállodát (18 három csillagos, 31 négy csillagos, 1 öt csillagos) vizsgáltunk meg kérdöiv segitségével, valamint weblapjuk elemzésével a szolgáltatásaik, és a kinálati elemek tekintetében. Eredményeink azt mutatták, hogy a vizsgált szállodák többségében a relaxációs szolgáltatások, az egyéb közérzetjavitó, testápolási szolgáltatások, és orvosesztétikai kezelések különbözö mértékbe ugyan, de megtalálhatók. Leggyakoribb a masszázs, ami a szállodák többségének kinálatában megjelenik, de a többi szolgáltatástipusból is széles repertoárt kinálnak a vendégek számára.

Kulcsszavak: relaxációs szolgáltatások, masszázs, kinálati elemek JEL: 12WSA 


\title{
RELAXATION AND WELL-BEING SERVICES OFFERED BY HOTELS IN THE NORTHERN GREAT PLAIN REGION
}

\begin{abstract}
People want to rest, relax, recharge during their stay, so they look for that in the hotel services. Experience, pampering, and health consciousness are increasingly appearing in people's choices of resort offerings. As the pursuit of health, relaxation and well-being appear as a need during holidays, its effect is also reflected in the choice of tourist destinations and is reflected in the preference system of services. Because of the importance of tourism in the Northern Great Plain Region, we investigated these services in a 3-5 star hotel in the region. We surveyed 50 hotels (18 three-star, 31 four-star, 1 five-star) through a questionnaire and website analysis for their services and offerings. Our results showed that relaxation services, other wellness services, personal care services, and medical aesthetic treatments are found to varying degrees in most of the hotels examined. The most common type of massage is the majority of hotels, but they also offer a wide repertoire of other types of services.
\end{abstract}

Keywords: relaxation services, massage, supply elements 


\section{Bevezetés}

A szállodák értékelésénél a csillagszám alapján tudjuk, hogy minél több csillaggal rendelkezik egy szálloda, annál jobb szolgáltatásokat nyújt a vendégek számára. Magyarországon a 239/2009. (X. 20.) Kormányrendelet szabályozza a kereskedelmi szálláshelyek üzemeltetési feltételeit, és rendelkezik a szállodák kötelező minősítéséről. A Nemzetgazdasági Minisztérium és a Magyar Szállodák és Éttermek Szövetsége megállapodásának értelmében egy kategóriánként egységes európai minősítő követelményrendszer alapján sorolják be a szállodákat egytől öt csillagig. Egy korábbi (45/1998. (VI. 24.) IKIM) rendelet értelmében, mely a kereskedelmi és a fizetővendéglátó szálláshelyeket osztályba sorolta, a wellness szállodáknál találkoztunk olyan követelményekkel, mely a szálloda által nyújtott szolgáltatásokat, az egyes szállodai szaktevékenységeket, illetőleg az erre vonatkozó szakképzettséggel rendelkező személyeket, az egészséges életvitelhez szükséges gasztronómiai, sport, relaxációs, illetve wellness szolgáltatások, programlehetőségeket nyújtását elöírta. E korábbi rendelet értelmében a wellness szállodáknak 1 féle beltéri fürdőmedencével, 2 féle szauna vagy gőzfürdő létesítménnyel, 4 féle szépségápolási szolgáltatással, és legalább 6 féle masszázs, relaxációs és egyéb közérzetjavító - vizes és száraz - szolgáltatást kellett kínálnia. Ez utóbbihoz hozzá tartozott a masszázson kívül az akupunktúra, akupresszúra, izzasztó pakolás, kiropraktika, Bach-terápia, kneipp kúra, léböjt, életmód-táplálkozási tanácsadás, sóbarlang. Természetesen további előírások szabályozták még, a gasztronómiai kínálatot, a szabadidős sportolási lehetőségeket, a szakképzettség meglétét, a kulturális programokat is. Jelenleg ez a törvény változásával, a 239/2009. (X. 20.) Kormányrendelet érvénybe lépésével olyan formában módosult, hogy egységes európai követelménynek megfelelően pontszámokkal jelölik az egyes feltételeket, és szolgáltatásokat aminek meg kell felelni, csillagszámtól függően. A követelményrendszer értelmében az egy csillag megszerzéséhez 90, kettőéhez 170 pontra van szükség minimum. Egy három csillagos szállodának minimum 250 pontot kell elérni, míg egy négy csillagosnál 380 pontot, 5 csillagosnál 570 pontot írnak elő. Ezen felül a superior kategóriához további pontok elérése szükséges, egy és két csillag esetében 80 pont, három csillagosnál további 130 pont, négy csillagosnál 190, míg öt csillagosnál 80 pont. A jelenlegi szabályozás értelmében a szabadidős tevékenységek meghatározásánál a szállodáknak a minősítő rendszerben kötelező előírások nem szerepelnek, mint a korábbi szabályozásban (Müller et al., 2005; Bujdosó - Pénzes, 2015), csak választási alternatívák a pontgyüjtésre. Itt kapnak helyet a korábbi wellness szállodák kívánalmai is, mint például a fitness terem, masszázs, relaxációs szoba, szauna, szépségápoláshoz kapcsolódó szolgáltatások, úszómedence, sporteszközök kölcsönzése.

A szállodáknak így a testápolási szolgáltatás (masszázs, testtekercselés, ultrahangos testkezelés), kapcsolatosan nincs konkrét kitétel, úgy, mint korábban, minimum anynyi, hogy ha ilyen szolgáltatást kínálnak a vendégek számára, akkor a helység méretét szabályozzák be. A masszázsszolgáltatásért például 2 pontot kaphat a szálloda, abban 
az esetben, ha rendelkezik egy minimum 10m2-es helységgel. Maximum viszont csak 6 pontot gyüjthet a kabinok számának megfelelően. Egy masszázshelység esetén 2, kettő esetén 4, míg 3 esetén hat pontot kaphatnak. Mint látható nem a szolgáltatástípusok számától függ a pontszám, hanem a helységek számától. Felmerül a kérdés, hogy ennek tekintetében a szolgáltatások kínálata milyen, hiszen bár nem kötelező, de a versenyképesség egyik meghatározó eleme (Müller et al., 2016).

Az előzőek tükrében vizsgáljuk meg a relaxációs és közérzetjavító szolgáltatásokat. Számos típus tartozhat ide, pl. a következők: akupunktúra, akupresszúra, sóbarlang, sókamra, iriszdiagnosztik, iszappakolás, köpölyözés, gerinctorna, testledörzsölés, relaxációs technikák, masszázsok, légzésterápia , kineziológia, terápiák (hang, fény, aroma), stb. Úgy tűnik, hogy ezek egyre inkább megjelennek a wellness trendek között is, és a szállodák, fürdők vagy gyógyintézmények kínálatában is nagyobb szerepet kapnak (Müller et al., 2011,, Müller 2018). A szállodák érdeke, hogy minél szélesebb repertoárt kínáljanak a vendégek számára. A kínálati trendekben megjelenő élménynyújtás, az egyediség, az indivídum szerepe, a helyi specialitásokhoz való igazodás, a keleti és a nyugati irányzatok ötvöződése, a komplexitás megjelenésében is megfigyelhető (Fónagy, 2009).

Napjaink rohanó életmódja mellett az embereknek szüksége van pihenésre, kikapcsolódásra (Müller-Bácsné 2018). A belföldi, turisztikai célú többnapos utazások adatai a 2008-2017-es időszakban vizsgálva, az utazás célja szerint, azt mutatják, hogy leginkább a szórakozás és a pihenés (61\%) a fó utazási motívum (Biró et al 2019). Az emberek a pihenés alatt szeretnének kikapcsolódni, ellazulni, feltöltődni, így a szolgáltatásokban ezt keresik (Müller-Szabó 2009, Borbély-Müller 2015, Boda et. al. 2018). Az Észak-Alföldön, habár az idegenforgalom szerepe fontos tényező (Müller-Könyves 2006), ugyanakkor a szálláshely-szolgáltatás, a vendéglátás az országos átlagosnál kisebb (Biró et al., 2019). Az elmúlt években, 2014 és 2017 között, nőtt a férőhelyek száma, és az előrejelzés is azt mutatja, hogy ez továbbra is növekedni fog (Biró et al 2019). Természetesen ez számos tényezőtől függ, de ez egyik ezek közül, hogy mennyire népszerü a régió a turisták körében, míg ugyancsak lényeges, hogy a kínált szolgáltatások vonzóak legyenek az ide érkezők számára (Hidvégi et al., 2015; Biró - Müller 2017; Lenténé et al., 2018).

\section{Módszer}

Kutatásunk során a relaxációs és a közérzetjavító szolgáltatásokra koncentráltunk. Célunk megvizsgálni, ezen kínálati elemek megjelenését az Észak-alföldi régió 3-5 csillagos szállodáinak szolgáltatásaiban. A kínálat elemzése volt a célunk. A kvantitatív eljárás során előtesztelt kérdőívet alkalmaztunk, melyben számos szolgáltatás felmérése szerepelt, így a relaxációs és a közérzetjavító szolgáltatások felmérése csak egy kis részét képezték a komplex vizsgálatnak. Az alábbi témakörök kaptak helyt a kérdőívben az egészségmegőrzés le- 
hetőségei, wellness szolgáltatások, sport és szabadidős, valamint gyógyászati szolgáltatások megjelenése a szállodák kínálatában. Jelen tanulmányunkban kizárólag a relaxációs és az egyéb közérzetjavító szolgáltatások kínálati elemeit mutatjuk be.

A kutatásban 50 szállodát (18 három csillagos, 31 négy csillagos, 1 öt csillagos) vizsgáltunk meg kérdőív segítségével, valamint weblapjuk elemzésével a szolgáltatásaik, és a kínálati elemek tekintetében. Az Észak - alföldi régióra tekintve a minta reprezentatív, hiszen minden 3 csillagos, és a fölötti szálloda bekerült a vizsgálatba. Azokban az esetekben, ahol a szállodák nem töltöttök ki az adott kérdést, vagy a megadott válaszok nem egyeztek a részletes felsorolással, ott még az honlapos elemzést alkalmaztuk. A wellness szolgáltatások árlistáit, és a szálloda honlap kínálatát elemezve jutottunk további adatokhoz. Az adatfelvételre 2018-ban került sor.

\section{Eredmények}

Az vizsgált szállodák 84 \%-ban van masszázs, (átlag 6,14 masszázstípus fordul elő, szórás 5,2), míg a szállodák 16\%-ában nincs ilyen jellegű szolgáltatás. Az ötven szállodában összesen 48 féle masszázstípust kínálnak a vendégek számára. Egy öt csillagos szálloda van a régióban, ahol 9 féle masszázsszolgáltatást kínálnak a vendégeknek. A csillagszám függvényében vizsgálva azt mondhatjuk, hogy a négy csillagos szállodákban átlag 7,35, míg a három csillagosban átlag 4,16 masszázstípust ajánlanak a vendégek számára. A legtöbb 22 féle masszázskínálat volt, de 12 szállodánál 10 fölötti volt a kínálat típusa. A leggyakrabban előforduló masszázstípusok a frissítő, vitalizáló masszázs (62\%), a talpmasszázs (58\%), a svédmasszázs (56\%), az aromaterápiás masszázs (50\%) és a relaxáló, stresszoldó masszázs (50\%), gyógymasszázs (50\%).

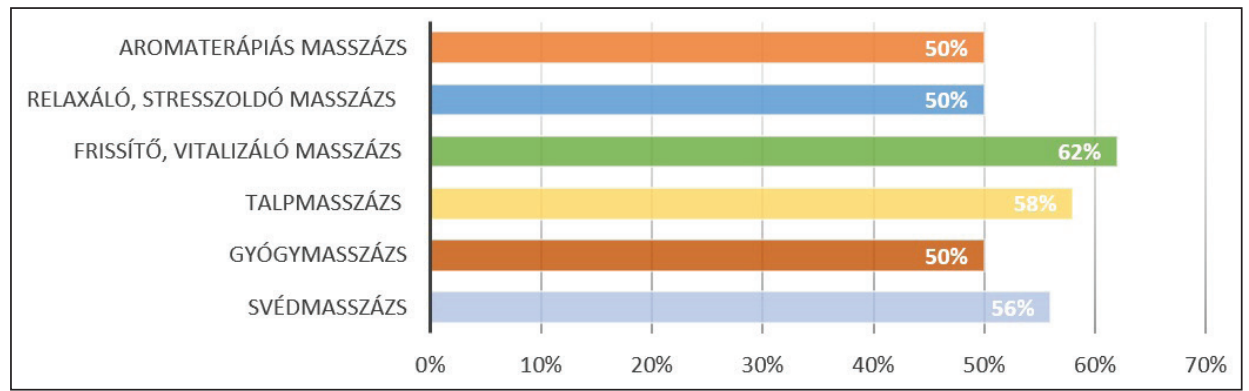

1. ábra: A leggyakrabban előforduló masszázskezelések az Észak-alföldi

(3-5 csillagos) szállodák kínálatában

Forrás: saját kutatás, saját szerkesztés 
A vizsgált szállodák kínálatában a cellulit masszázs 20\%-ban volt jelen, cellulit, alakformáló, vagy karcsúsító masszázs néven. További 14 \%-ukban nyirok masszázs, méregtelenítő nyirokmasszázs, 2\%-ban méregtelenítő masszázs, és további 2\%-ban pedig kötőszöveti masszázs elnevezéssel találkoztunk. Egy-egy szállodában kínáltak ayurvedikus masszást, anti-aging masszást, reflexmasszázst, valamint köpölyös maszszázst. A svédmasszázs az a lazító, frissítő fajta alapmasszázs melyet a legtöbb szállodában (56\%) megtalálunk a kínálatban. Emellett viszont megjelennek a Távol-keleti, ősi, tradicionális masszázsfajták, mint amilyen az Indiai testmasszázs (4\%), a Shi-Tao (4\%), és a Tibeti hangmasszázs (4\%). A Thai masszázs a szállodák kínálatában előkelő helyen szerepel (14\%). A Shiatsu masszázs a kínálatban (6\%), mindössze három szállodánál volt. Egy -egy szállodánál találtunk Finn, és egynél Hungarikum maszszázst a kínálati elemek között.

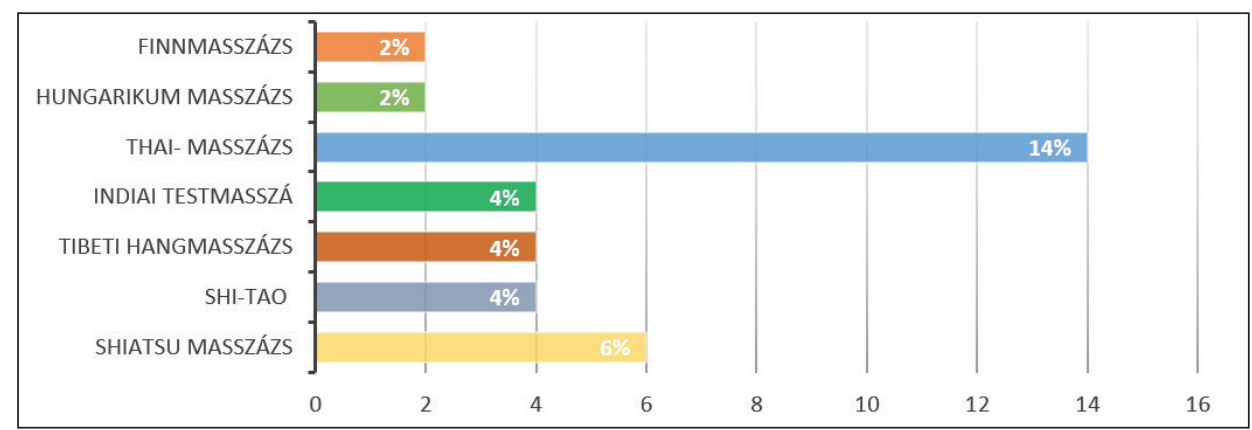

\section{2. ábra A különleges masszázskezelések szolgáltatásainak előfordulása az Észak-alföldi (3-5 csillagos) szállodák kínálatában \\ Forrás: saját kutatás, saját szerkesztés}

A masszázskínálatban olyan masszázstípusok is megjelentek, melyekhez különleges eszközöket alkalmaznak, mely segíti, kiegészíti a kezelést. Egyik ilyen volt a lávaköves masszázs 18\%-ban jelent meg a kínálatban, valamint a 2\%-ban a jádeköves masszázs. A hidromasszázs a szállodák 16\%-ában volt kínálati elem. Egyéb eszközös típusok is megjelentek a kínálatban, mint például a bambuszrúd masszázs (4\%), a labdacsos masszásnál (2\%), speciális gyógynövényekkel és füszerekkel töltött kis ladbacsokat, zsákokat alkalmaznak, a szárazkefe masszázs (2\%), ahol egy durva kefével dörzsölik végig az egész testet, és a Kneipp féle taposó masszázs (2\%).

A masszázs által kifejlett hatások növelése érdekében különféle illóolajok, herbáriák, alkalmazása is gyakori. Míg egyes hatóanyagok a cellulit masszázs kiegészítő kellékei, pl a fahéj, vagy a pirospaprika pakolás, addig némelyik a stresszoldást, míg más a bőr fiatalítását segíti elő. Erre a vizsgált szállodákban sokféle kínálattal találkoztunk. $\mathrm{Az}$ aromaterápiás kezelések voltak többségben melyet aromamasszázs, aromaolajos 
masszázs $(50 \%)$ néven is hirdettek. Találkoztunk forró olajos herbál masszázzsal (4\%), és ezen felül külön gyógyfüves masszázs $(6 \%)$ is szerepelt a kínálatban, mely nem azonos az előzőekkel. A labdacsos masszázst már korábban említettük, de itt is szükségesnek tartjuk, hiszen itt is gyógyfüveket alkalmaznak a masszírozás során, csak annak felhasználási módja különböző. Ha mindezeket összesítjük, akkor az aromás, herbáriás masszázstípusok a szállodák több mint felénél (72\%) megtalálhatók. A csokoládé (28\%) és a méz (18\%) masszás ugyancsak több szálloda kínálatában megjelent. A rózsaolajos (8\%), a tengeri sós (4\%),

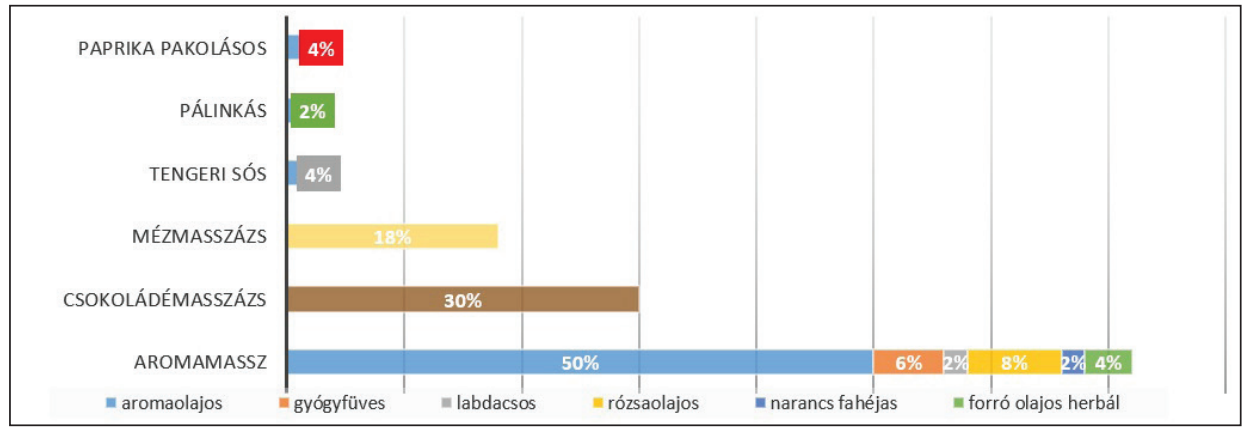

3. ábra: A különleges masszázskezelések az Észak-alföldi (3-5 csillagos) szállodák kínálatában

Forrás: saját kutatás, saját szerkesztés

Az egyéb testápolási szolgáltatásokat is vizsgáltuk. Testtekercselés egy szállodában sem volt a szolgáltatások között, míg az ultrahangos testkezelés a szállodák 8\%-ában fordult elő. A reflexológia 1 szállodában, a Bemer érterápiás kezelés 2 szállodában, a fényterápia pedig 3 szállodában szerepelt a kínálatban.

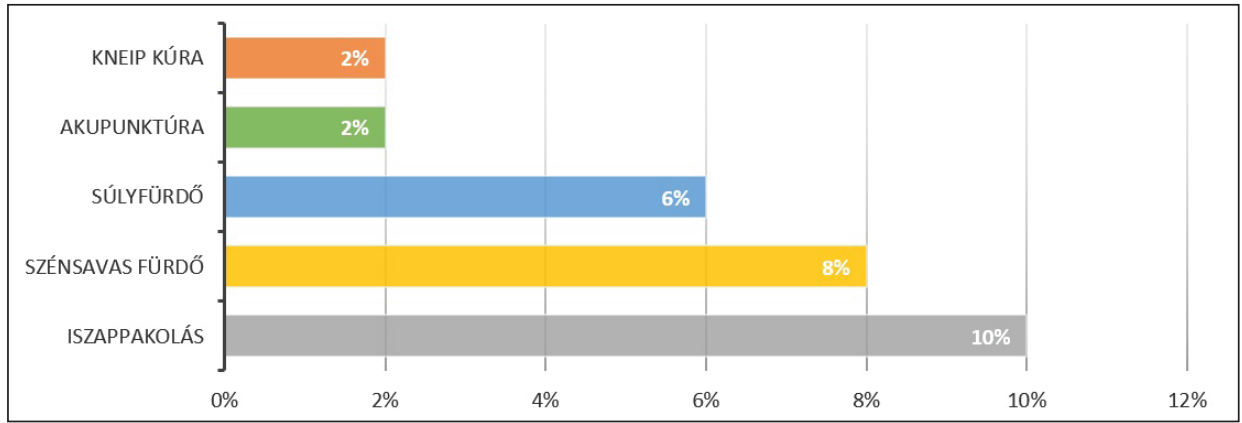

4. ábra az egyéb kínálati elemek előfordulása az Észak-alföldi (3-5 csillagos) szállodák szolgáltatásaiban

Forrás: saját kutatás, saját szerkesztés 
Az orvosesztétikai kezelések a szállodák 10\%-ában volt jelen. Ezek közül a szolgáltatások közül az alakformálás, arc fiatalítás, mezoterápia, GUNA bioterápia, plasztikai sebészet, érsebészet, gyomorballon beültetés, anti ageing, fogászati kezelések, lézeres szépészeti kezelések és eljárások, valamint a bőrgyógyászat szerepelt a kínálatban. Az egyéb testápolási szolgáltatásoknál, mely a vizsgált szállodák $18 \%$ - ban volt jelen leggyakoribb kínálati elem az iszappakolás volt 10\%-ban. Az OEP által támogatott gyógykezelések jelentek meg leginkább a kínálatban, mint az iszappakolás, a súlyfürdő (6\%), a szénsavas fürdő (8\%), az orvosi masszázs, a vízalatti sugármasszázs, a vízalatti csoportos torna, az akupunktúra (2\%), a kneip kúra (2\%). A szállodák 22\%-ban rendelkeztek só barlanggal vagy só szobával. Egy szállodában sem kínáltak izzasztó pakolást, kiropraktikát, vagy Bach-terápiát. A léböjt, az életmód-táplálkozási tanácsadás a vizsgált szállodák közül mindössze egyben volt a kínálati elemek között.

\section{Összegzés}

A szállodák kritériumrendszerét a kereskedelmi szálláshelyek osztályba sorolásáról többször módosították. A jelenleg érvényben lévő törvény szerint kategóriánként egységes európai minősítő követelményrendszer alapján sorolják be a szállodákat egytől öt csillagig. A jelenlegi besorolás alapján a szállodáknak pontokat kell gyűjteni, melynek vannak minimum követelményei. A szabadidős és wellness elemek a kategóriarendszerben a szabadon választható közé tartozik, ami azt jelenti, hogy az adott szálloda dönti el, hogy az egyes szolgáltatásokat megjeleníti a kínálatában, vagy sem. Felmerült bennünk a kérdés, hogy a szállodák ennek tekintetében milyen mértékben kínálnak relaxációs és közérzetjavító szolgáltatásokat. Azt feltételeztük, hogy a szállodák kínálata a szolgáltatásbővítések miatt, melyet korábbi kutatásunkban (Biró et al., 2019, Lenténé et al., 2019; Hidvégi et al., 2019) kimutattunk pozitív képet ad a relaxációs és közérzetjavító szolgáltatások elemeiről. Ez a feltételezésünk bizonyosságot nyert, hiszen a szállodák a kínálatbővítésében számos típus megjelenik. Leggyakoribb a masszázsszolgáltatás, de emellett az orvosesztétikai kezelések, és az egyéb testkezelések is helyet kapnak. A masszázs ilyen arányú megjelenése nem meglepő, hiszen a wellness-turizmus fö szolgáltatási kategóriái közé tartozik, így nem véletlen, hogy a masszázs-szolgáltatást a szállodák kínálatában a vendégek a fontos tényezők közé sorolták (Árpási 2014) azon tényezőkkel együtt, hogy a hotelben legyen medence, lehessen szaunázni és legyen biztosítva az orvosi felügyelet. A leggyakrabban előforduló masszázstípusok a frissítő, vitalizáló masszázs, a talpmasszázs, a svédmasszázs, az aromaterápiás masszázs és a relaxáló, stresszoldó masszázs, de emellett sokféle különleges masszázstípust kínálnak a szállodák a vendégeknek. Az orvosesztétikai kezelések közül megtalálhatók a szállodák kínálatában az alakformáló eljárások, az arc fiatalítás, 
plasztikai sebészet, lézeres szépészeti kezelések és eljárások, a bőrgyógyászat a mezoterápia, GUNA bioterápia, az érsebészet, a gyomorballon beültetés, az anti ageing, és fogászati kezelések. Az egyéb testápolási szolgáltatásoknál leggyakoribb kínálati elem az iszappakolás mellett az OEP által támogatott gyógykezelések jelentek meg leginkább a kínálatban, mint az iszappakolás, a súlyfürdő, a szénsavas fürdő, az orvosi masszázs, a vízalatti sugármasszázs.

A publikáció elkészitését az EFOP-3.6.2-16-2017-00003 számú projekt támogatta. A projekt az Európai Unió támogatásával, az Európai Szociális Alap társfinanszirozásával valósult meg.

\section{Hivatkozott források}

[1.] Árpási Z. (2014): wellness turisztikai szolgáltatások fejlesztésének lehetőségei a dél-alföldirégióban. doktori értekezés https://szie.hu/file/tti/archivum/ Arpasi_Zoltan_ertekezes.pdf

[2.] Bíró M. - Müller A. (2017) Aktív pihenés, rekreáció = Active relaxation, recreation In: Dobos, Anna; Mika János - Természeti és kultúrtörténeti értékek Eger térségében = Natural and cultural heritage in the Eger Region Eger, Magyarország: Líceum Kiadó, (2017) pp. 128-130., 3 p.

[3.] Biró M. - Tatár A. - Pucsok J. M. - Lenténé Puskás A. - Mikhárdi S. Hidvégi P. - Molnár A. (2019): Az Észak-alföldi régió szállodáinak egészségturisztikai trendjei In: Balogh, László (szerk.) Sokoldalú sporttudomány Debrecen, Magyarország: Debreceni Egyetem Sporttudományi Koordinációs Intézet, pp. 9-20. , 12 p.

[4.] Boda E. - Bácsné B. É. - Müller A. (2018): Motiváció vizsgálata a kalandpark-látogátók körébén. International Journal of Engineering And Management Sciences / Müszaki és Menedzsment Tudományi Közlemények 3: 3. pp. 106-126., 21 p. (2018)

[5.] Boda E. - Honfi L. - Bíró M. - Révészn L. - Müller A. (2015): A szabadidő eltöltésének és a rekreációs tevékenységek vizsgálata egri lakosok körében Acta Academiae Paedagogicae Agriensis Nova Series: Sectio Sport 42 pp. 49-62., 14 p.

[6.] Borbély, A. - Müller A. (2015): Sport és turizmus. Debrecen, Magyarország: Campus Kiadó (2015), 110 p. 
[7.] Bujdosó Z. - Pénzes J. (2015): Tourism competitiveness and tourism development in the border regions of Hungary. In: Vladimir, TRUKHACHEV (szerk.) Sustainable Development of Tourism Market: International Practices and Russian Experience. Stavropol, Oroszország : Stavropol State Agrarian University, (2015) pp. 18-26.

[8.] Hidvégi P. - Biró M. - Lenténé Puskás A. - Pucsok J. M. - Tatár A. - Bárdos K. (2019): Wellness szolgáltatást igénybevevők felmérése az Észak-alföldi régióban In: Balogh, László (szerk.) Sokoldalú sporttudomány Debrecen, Magyarország: Debreceni Egyetem Sporttudományi Koordinációs Intézet, pp. 1-8., 8 p.

[9.] Hidvégi P. - Bíró M. - Müller A. (szerk.) A rekreáció elmélete és módszertana 2.: Egészségfejlesztés Eger, Magyarország : Líceum Kiadó (2015) , 25 p. ISBN: 9786155621086

[10.] Lenténé Puskás A. - Biró M. - Dobay B. - Pucsok J.M. (2018): A szabadidő sportolás kínálati elemeinek, és szolgáltatásainak vizsgálata Magyarország Észak-alföldi régiójának szállodáiban Selye e-studies 9:1 pp. 13-21., 9 p. (2018)

[11.] Lenténé Puskás A. - Biró M. - Hidvégi P. - Molnár A. - Lente L. - Pucsok J.M. (2019): Analysis of the North Great Plain Region's Accommodation Supply with Special Focus on Sport and Wellness Element GEOSPORT FOR SOCIETY 10 : 1 pp. 15-24. Paper: /gss.1002-046, 10 p.

[12.] LenténéPuskás A. - Hídvégi P.-Tatár A. - Bíró M. - PucsokJ. (2019): A fürdős és medencés szolgáltatások megjelenése az Észak-alföldi régió szállodáiban. In: Sokoldalú sporttudomány / (szerk.) Balogh László, Debreceni Egyetem Sporttudományi Koordinációs Intézet, Debrecen, 54-62.

[13.] Lenténé Puskás, A. - Hídvégi P. - Tatár A. - Pucsok J. - Bíró M. (2018): A rekreációs turizmus lehetőségei Magyarországon az Észak-alföldi régióban. In: Fókuszban az egészség / Balogh, László (szerk.), Debreceni Egyetem Sporttudományi Koordinációs Intézet, Debrecen, 19-30.

[14.] Müller A (2018): Health tourism in Hungary.In: Jaromír, Šimonek; Beáta, Dobay (szerk.) Sport science in motion: proceedings from the scientific conference. Športová veda v pohybe: recenzovaný zborník vedeckých a odborných prác z konferencie. Mozgásban a sporttudomány: válogatott tanulmányok a konferenciáról.Komárno, Szlovákia : Univerzita J. Selyeho, (2018) pp. 8-15. , 8 p. 
[15.] Müller A. - Bácsné, B. É. (2018): Az egészséges életmód és a sport kapcsolata. Létavértes, Magyarország: Létavértes SC '97 Egyesület, 96 p. ISBN: 9786150031897

[16.] Müller A. - Barcsák B. - Boda E.J. (2016): Health tourism the cavebath of Miskolctapolca.In: György, Juhász; Enikő, Korcsmáros; Erika, Huszárik (szerk.) Korszerü szemlélet a tudományban és az oktatásban. Gazdaságtudományi szekció: Zborník medzinárodnej vedeckej konferencie Univerzity J. Selyeho - 2016 „Súcasné aspekty vedy a vzdelávania”. Sekcie ekonomických vied.Komárno, Szlovákia: Selye János Egyetem, (2016) pp. 233-245., 13 p.

[17.] Müller A. - Könyves E. - Szabó R. (2005): A wellness turizmus sokszínű kínálatának bemutatása. Iskolai Testnevelés és Sport - Elméleti Módszertani és Információs Szaklap 27. pp. 29-34. , 6 p. (2005)

[18.] Müller A. - Könyves E. (2006): Az egészségturizmus lehetőségei az Észak-alföldi régióban. Acta Academiae Paedagogicae Agriensis Nova Series: Sectio Sport 33 pp. 132-143., 12 p.

[19.] Müller A. - Ráthonyi G. - Bíró M. - Ráthonyi-Ódor K. - Bács Z. - Ács P. - Hegyi G. - Bácsné Bába É (2018): The effect of complex climate therapy on rehabilitation results of elderly asthmatic and chronic obstructive airways disease (COPD) patients European Journal Of Integrative Medicine 20 pp. 106-114. 9 p.

[20.] Szira Z. - Lajos A.: Health Consciousness in the Life Style and Scale of Values of the Hungarian Young People. In: Annals of the Polish Association of Agricultural and Agribusiness Economists. Vol. VII. No. 6. Warsaw-Poznan 2-16 p.(2005) http://kgk.uni-obuda.hu/sites/default/files/13_FodorMonika_SzilagyiTiborPal.pdf 


\section{Szerzők:}

\section{Biró Melinda}

egyetemi docens

Debreceni Egyetem

Sporttudományi Koordinációs Intézet

biro.melinda@sport.unideb.hu,

\section{Pucsok József Márton}

egyetemi docens

Debreceni Egyetem

Sporttudományi Koordinációs Intézet

pucsok.jozsef@sport.unideb.hu

\section{Hidvégi Péter}

egyetemi docens

Debreceni Egyetem

Sporttudományi Koordinációs Intézet

hidvegi.peter@sport.unideb.hu

\section{Lenténé Puskás Andrea}

egyetemi adjunktus

Debreceni Egyetem

Sporttudományi Koordinációs Intézet

lpandrea@sport.unideb.hu 